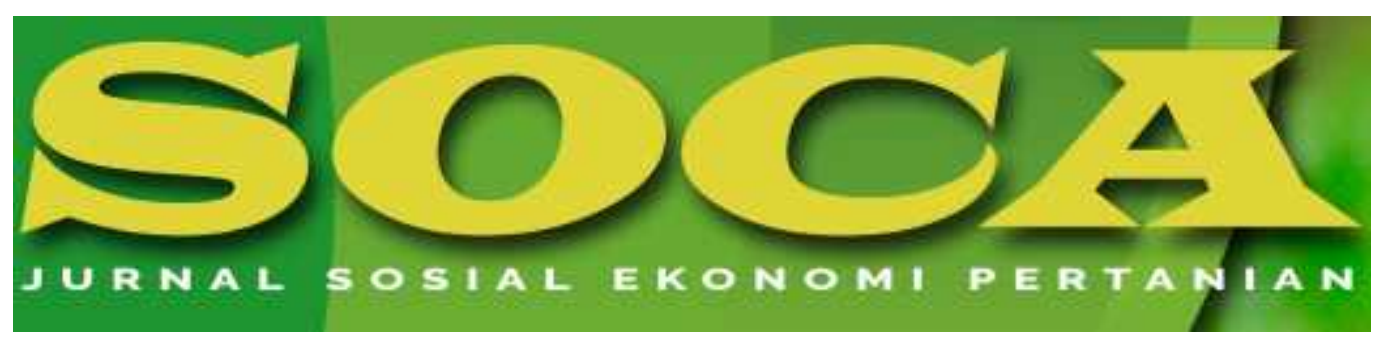

https://ojs.unud.ac.id/index.php/soca

\title{
ANALISIS NILAI TAMBAH KEDELAI SEBAGAI BAHAN BAKU TEMPE DI DESA ANGKATAN LOR, KECAMATAN TAMBAKROMO, KABUPATEN PATI
}

\author{
Wiwik Lestari, Djoko Sumarjono dan Titik Ekowati \\ 1 Program Studi Agribisnis Fakultas Peternakan dan Pertanian Universitas Diponegoro \\ Email: wiwiklestari082@gmail.com,HP:0895384390130
}

\section{Kata Kunci: \\ Kedelai, nilai tambah, tempe}

\begin{abstract}
Abstrak
Agroindustri merupakan kegiatan pengolahan hasil pertanian yang masih berupa produk primer menjadi produk sekunder atau tersier yang penting untuk dikembangkan. Pengembangan agroindustri diharapkan mampu menyerap hasil pertanian dari petani. Hasil pertanian yang masih berupa produk primer akan diolah menjadi produk sekunder atau tersier sehingga akan menghasilkan nilai tambah. Nilai tambah suatu produk sangat penting untuk meningkatkan harga jual produk tersebut. Tujuan dari penelitian ini adalah untuk (1) menghitung dan menganalisis nilai tambah tempe dari proses pengolahan sampai ke tangan konsumen, (2) menganalisis pengaruh jumlah kedelai, harga tempe dan sumbangan input lain terhadap nilai tambah tempe. Penelitian ini menggunakan metode sensus. Pengambilan sampel dilakukan dengan mengambil semua responden yang berjumlah 34 pengrajin tempe melalui wawancara dengan bantuan kuisioner. Nilai tambah dianalisis menggunakan metode Hayami. Uji perbedaan rasio nilai tambah tempe menggunakan one sample $t$ test. Pengaruh jumlah kedelai, harga tempe dan sumbangan input terhadap nilai tambah diuji dengan analisis regresi linear berganda. Hasil penelitian yang telah dilaksanakan menunjukkan bahwa nilai tambah yang diperoleh dari pengolahan kedelai menjadi tempe secara nyata tergolong sedang yaitu sebesar $34,65 \%$. Harga tempe dan sumbangan input lain berpengaruh secara nyata terhadap besarnya nilai tambah tempe, sedangkan jumlah kedelai tidak berpengaruh secara nyata. Besarnya nilai tambah yang dihasilkan menunjukkan bahwa usaha tempe tersebut dapat dikembangkan. Dalam rangka meningkatkan nilai tambah tempe disarankan pengrajin
\end{abstract}


tempe menurunkan biaya sumbangan input lain terutama pada biaya bahan bakar dan menaikkan harga jual tempe.

THE ANALYSIS OF SOY ADDED VALUE AS TEMPE RAW MATERIAL IN ANGKATAN LOR VILLAGE, TAMBAKROMO DISTRICT, PATI REGENCY

\begin{tabular}{l} 
Keywords: \\
Added value, \\
soybeans, \\
tempe. \\
\hline
\end{tabular}

\begin{abstract}
Abstrak
Agroindustry is one of the important sub-sectors to be developed. The development of agroindustry is expected to be able to absorb agricultural products from farmers. Agricultural products that are still in the form of primary products will be processed into secondary or tertiary products so that they will produce added value. The added value of a product is very important to increase the selling price of the product. The purpose of study are (1) calculate and analyze the value of tempe from the processing process to the consumer's hand, (2) analyze the effect of the amount of soybeans, the price of tempeh and the contribution of other inputs to the added value of tempe. The method used in this study is the census method. Sampling is done by taking all respondents totaling 34 tempe producers through interviews with the help of questionnaires. The added value was analyzed using the Hayami method. Test the difference in tempe value-added ratio using one sample $t$ test. The test of the effect of the amount of soybeans, the price of tempe and the contribution of other inputs to added value using Multiple Linear Regression. Based on the results of the study it can be seen that the added value obtained from the processing of soybeans into tempe is significantly classified as moderate, which is equal to $34.65 \%$. The price of tempe and the contribution of other inputs have a significant effect on the amount of added value of tempe, while the amount of soybeans does not significantly influence. The amount of added value produced shows that the tempe business can be developed. In order to increase the added value of tempe, tempe producers are advised to reduce the contribution costs of other inputs, especially on fuel costs and increase the selling price of tempe.
\end{abstract}

How to Cite (APA 6 ${ }^{\text {th }}$ Style):

Lestari, W., Sumarjono, D., \& Titik Ekowati. (2019). Analisis Nilai Tambah Kedelai Sebagai Bahan Baku Tempe di Desa Angkatan Lor, Kecamatan Tambakromo, Kabupaten Pati. SOCA: Jurnal Sosial Ekonomi Pertanian, 13(3), 409-419. https://doi.org/https://doi.org/10.24843/SOCA.2019.v13.i03.p10 


\section{PENDAHULUAN}

Pertanian merupakan sektor ekonomi penting sebagai sumber pangan untuk kelangsungan hidup masyarakat. Subsektor pertanian khususnya tanaman pangan menjadi salah satu fokus pengembangan pertanian saat ini karena tanaman pangan menjadi penyumbang pendapatan negara terbesar di sektor petanian.

Kegiatan mengolah bahan mentah menjadi produk semi mentah atau produk jadi pada komoditas pertanian sangat penting untuk dilakukan. Kegiatan ini sering disebut dengan istilah agroindustri. Pengembangan agroindustri diharapkan mampu menyerap hasil pertanian dari petani. Hasil pertanian yang masih berupa produk primer akan diolah menjadi produk sekunder atau tersier sehingga akan menghasilkan nilai tambah. Nilai tambah suatu produk sangat penting untuk meningkatkan harga jual produk tersebut.

Kedelai tergolong tanaman pangan yang sangat penting bagi masyarakt Indonesia. Kedelai dapat diolah menjadi berbagai produk makanan misalnya tempe. Tempe adalah makanan asli dari Indonesia yang berbahan dasar kedelai. Tingkat konsumsi tempe masyarakat Indonesia relatif tinggi dikarenakan kandungan gizi yang cukup tinggi dan harganya yang murah. Nilai gizi protein pada tempe lebih tinggi daripada bahan asalnya (kedelai) sebagai akibat terjadinya pembebasan asam amino selama proses fermentasi (Salim, 2012). Konsumsi tempe rata-rata per kapita di Indonesia diperkirakan sebesar 20,2 gram per hari, lebih rendah sedikit dari konsumsi tahu yaitu 21,6 gram per hari (BPS, 2016). Meningkatnya kesadaran masyarakat akan sumber pangan yang bergizi dengan harga terjangkau pasti akan meningkatkan permintaan terhadap produk tempe sehingga potensi pasar akan terbuka lebar.

Berdasarkan penelitian terdahulu yang dilakukan oleh Purnamasari (2017) menunjukkan bahwa industri rumah tangga tempe mampu menghasilkan nilai tambah $\mathrm{Rp} 7.286 / \mathrm{kg}$ dengan rasionya adalah 43,45\%. Industri tempe memiliki kontribusi yang sangat besar pada total pendapatan rumah tangga pengrajin $(93,38 \%)$. Penelitian lain yang berkaitan dengan nilai tambah juga dilakukan oleh Soehyono et al. (2014) yang menunjukkan bahwa agorindustri tempe memberikan nilai tambah sebesar Rp 5.331,64 per kilogram.

Desa Angkatan Lor merupakan salah satu sentra produksi tempe di Kabupaten Pati. Jumlah usaha rumah tangga tempe ada 34. Desa Angkatan Lor juga berbatasan langsung dengan Kecamatan Gabus yang merupakan salah satu sentra produksi, pengolahan serta pengemasan kedelai (Syaifuddin, 2013). Mayoritas usaha tempe masih berskala rumah tangga berdasarkan kapasitas produksi dan tenaga kerja yang digunakan.

Usaha tempe di Desa Angkatan Lor sudah berlangsung lama bahkan ada beberapa usaha yang turun temurun, namun belum memiliki pembukuan keuangan yang baku. Hal ini menyebabkan biaya yang dikeluarkan tidak terperinci secara detail sehingga akan berpengaruh pada tidak stabilnya nilai tambah yang dihasilkan. Permasalahan tersebut ditambah dengan beberapa penelitian terdahulu memberikan sumbangan pemikiran kepada penulis untuk melakukan penelitian tentang nilai tambah tempe.

Penelitian ini bertujuan untuk (1) menghitung dan menganalisis nilai tambah tempe dari proses produksi sampai ke tangan konsumen, (2) menganalisis 
pengaruh jumlah kedelai, harga tempe dan sumbangan input lain terhadap nilai tambah tempe. Manfaat penelitian ini bagi pemilik usaha tempe yaitu dapat digunakan sebagai pedoman dalam memperhitungkan biaya produksi tempe sehingga dapat mengurangi kerugian yang dialami.

\section{METODOLGI PENELITIAN}

Waktu pelaksanaan penelitian yaitu pada bulan Oktober-November 2018 di Desa Angkatan Lor, Kecamatan Tambakromo, Kabupaten Pati. Alasan pemilihan lokasi penelitian dikarenakan Desa Angkatan Lor menjadi sentra usaha pembuatan tempe di Kecamatan Tambakromo. Desa Angkatan Lor juga berbatasan langsung dengan Kecamatan Gabus yang merupakan salah satu sentra produksi, pengolahan serta pengemasan kedelai (Syaifuddin, 2013). Penelitian ini menggunakan metode sensus. Jumlah usaha pembuatan tempe di Desa Angkatan Lor adalah 34. Pengambilan data dilakukan melalui cara wawancara dan observasi.

1. Wawancara

Peneliti memberikan pertanyaan kepada respoden berdasarkan kuesioner yang telah disusun sebelumnya. Wawancara digunakan untuk memperoleh informasi secara detail tentang kondisi di lokasi penelitian. Data primer yang diambil terdiri dari jumlah kedelai, sumbangan input lain, tenaga kerja, dan peralatan produksi.

2. Observasi

Observasi adalah pengamatan langsung terhadap kondisi usaha tempe pada masing-masing responden. Misalnya pengamatan langsung pada proses pembuatan tempe.

Tujuan pertama dihitung dan dianalisis menggunakan metode Hayami (Agustina et al., 2015). Metode Hayami digunakan untuk menghitung nilai tambah tempe yang dihitung secara kuantitatif per proses produksi.

Hipotesis pertama diuji menggunakan uji one sample $t$ test unutk melihat apakah ada perbedaan antara nilai satu kelompok dengan keompok lainnya yang tidak saling berhubungan (Riduwan, 2010). Hipotesis statistik sebagai berikut:

$\mathrm{H}_{0}: \mu-\mu_{0}=15 \%$

Ha : $\mu-\mu_{0} \neq 15 \%$

Tujuan kedua dianalisis dan diuji menggunakan metode regresi linear berganda untuk melihat apakah jumlah kedelai, harga tempe dan sumbangan input lain berpengaruh terhadap nilai tambah atau tidak. Berikut ini adalah model persamaan regresi linear berganda (Engko, 2008):

$$
\mathrm{Y}=\mathrm{a}+\mathrm{bX}_{1}+\mathrm{cX} \mathrm{X}_{2}+\mathrm{dX} \mathrm{X}_{3}+\mathrm{e}
$$

Keterangan:

$\mathrm{Y}=$ Nilai Tambah $(\mathrm{Rp} / \mathrm{kg})$

$\mathrm{X}_{1} \quad=$ Jumlah Kedelai $(\mathrm{kg})$

$\mathrm{X}_{2} \quad=$ Harga Tempe $(\mathrm{Rp} / \mathrm{kg})$

$\mathrm{X}_{3} \quad=$ Sumbangan Input Lain $(\mathrm{Rp} / \mathrm{kg})$

$\mathrm{b} \quad=$ Koefisien regresi variabel jumlah kedelai

c = Koefisien regresi variabel harga tempe

$\mathrm{d}=$ Koefisien regresi variabel sumbangan input lain 
$\mathrm{e} \quad=$ Eror

\section{HASIL DAN PEMBAHASAN}

\section{Gambaran Umum Desa Angkatan Lor}

Desa Angkatan Lor berbatasan dengan beberapa desa yaitu bagian utara adalah Desa Gabus, bagian barat Desa Kedalingan, bagian selatan berbatasn dengan Desa Karangwono, sebelah timur adalah Desa Kudur, Kecamatan Winong. Luas wilayahnya sekitar 113,833 Ha yang sebagian besar penduduknya bekerja sebagai petani. Jumlah penduduk di Desa Angkatan Lor adalah 3.851 orang yang terdiri dari penduduk laki-laki 1.998 orang dan perempuan 1.863 orang. Desa Angakatan Lor merupakan salah satu sentra produksi tempe di Kabupaten Pati. Jumlah usaha rumah tangga tempe ada 34. Desa Angkatan Lor juga berbatasan langsung dengan Kecamatan Gabus yang merupakan salah satu sentra produksi, pengolahan serta pengemasan kedelai (Syaifuddin, 2013).

\section{Karakteristik Pengrajin Tempe}

Karakterisitik pengrajin tempe di Desa Angkatan Lor digolongakn berdasarkan usia, jenjang pendidikan, jumlah anggota keluarga dan lamanya usaha pembuatan tempe.

1. Usia Responden

Usia pengrajin tempe di Desa Angkatan Lor tergolong produktif yaitu ratarata 50 tahun. Usia produktif para pekerja berada pada kisaran antara 15-64 tahun (Putri dan Setiawina, 2013). Penggunaan tenaga kerja yang masih berusia produktif akan sangat menguntungkan karena masih memiliki kemampuan fisik dan psikis yang terbaik untuk membantu mengembangkan usaha.

2. Jenjang Pendidikan

Mayoritas pengrajin tempe di lokasi penelitian adalah lulusan SD. Hal ini dikarenakan pengrajin tempe merupakan pekerjaan yang biasanya menggunakan tenaga kerja terlatih bukan terpelajar. Beberapa pengrajin dengan tingkat pendidikan rendah ternyata memiliki volume produksi yang cukup besar, wilayah pemasaran yang luas dan pelanggan yang cukup banyak. Hal ini didukung oleh pendapat Tambunan dan Woyanti (2012) yang mengatakan jika produktivitas karyawan tidak dipengaruhi oleh tingkat pendidikan.

3. Jumlah Anggota Keluarga Responden

Hasil penelitian menunjukkan bahwa jumlah anggota keluarga responden rata-rata adalah 4 orang. Jumlah anggota keluarga dapat dimanfaatkan menjadi tenaga kerja dalam proses pembuatan tempe. Mayoritas usaha tempe di Desa Angakatan Lor menggunakan tenaga kerja dalam keluarga untuk mengolah tempe, sehingga akan mengurangi penggunaan biaya yang dikeluarkan.

4. Lamanya Usaha

Lamanya usaha merupakan lamanya pengrajin tempe dalam menjalankan usahanya. Hasil penelitian menunjukkan bahwa rata-rata pengalaman usaha tempe para pengrajin tempe di Desa Angkatan Lor adalah 19,5 tahun. Pengrajin tempe sudah memiliki pengalaman yang cukup berdasarkan lamanya usaha yang dijalankan. 


\section{Analisis Biaya Pembuatan Tempe}

Biaya produksi usaha tempe adalah biaya total yang dikeluarkan untuk membuat tempe. Biaya produksi terdiri dari biaya tetap dan variabel:

a. Biaya Tetap

Penyusutan peralatan dihitung sebagai biaya tetap karena tidak akan mempengaruhi jumlah tempe yang dihasilkan.

Tabel 2. Rata-rata Biaya Penyusutan Usaha Tempe per Produksi Tahun 2019

\begin{tabular}{|c|c|c|c|}
\hline No. & Macam Alat & Biaya & Persentase \\
\hline & & ------------Rp---------- & |--------------\%o------------- \\
\hline 1. & Mesin Giling & 465,11 & 19,33 \\
\hline 2. & Dandang & 369,64 & 15,36 \\
\hline 3. & Saringan Kayu & 816,28 & 33,92 \\
\hline 4. & Sotel Kayu & 336,83 & 14,00 \\
\hline 5. & Tampah & 208,22 & 8,65 \\
\hline 6. & Ember Plastik & 139,20 & 5,78 \\
\hline 7. & Drum & 70,99 & 2,95 \\
\hline & Total & $2.406,27$ & 100,00 \\
\hline
\end{tabular}

Sumber: Data primer penelitian yang diolah, 2019.

Rata-rata biaya penyusutan alat pada usaha tempe adalah $\mathrm{Rp}$ $2.406,27$ / produksi. Sumber biaya penyusutan terbesar berasal dari saringan kayu yaitu sebesar Rp 816,28 atau 33,92\%. Hal itu dikarenakan umur ekonomis saringan kayu hanya 0,5 tahun sehingga sering dilakukan penggantian alat baru. Biaya penyusutan terkecil berasal dari alat berupa drum yaitu sebesar Rp 70,99 atau 2,95\%. Drum memiliki umur ekonomis cukup lama yaitu 5 tahun dan tidak membutuhkan biaya perawatan.

a. Biaya Variabel

Biaya variabel dalam proses pembuatan tempe melipuit biaya pembelian kedelai, sumbangan input lain dan tenaga kerja. Komponen biaya tersebut akan berubah tergantung dengan jumlah tempe yang dihasilkan

1. Kedelai

Kedelai yang digunakan untuk membuat tempe rata-rata adalah 65 $\mathrm{kg} /$ produksi tempe dengan biaya sebesar Rp 508.397 per produksi. Rata-rata harga kedelai yang digunakan untuk membuat tempe oleh pengrajin sebesar Rp $7.724 / \mathrm{kg}$.

2. Sumbangan Input Lain

Biaya ini meliputi biaya bahan pembuatan tempe selain kedelai dan tenaga kerja. Penggunaan biaya rata-rata sumbangan input lain terlihat pada Tabel 3.

Tabel 3. Rata-Rata Biaya Sumbangan Input Lain per Produksi pada Usaha Tempe Tahun 2019

\begin{tabular}{|c|c|c|c|}
\hline No. & Bahan & $\begin{array}{c}\text { Jumlah } \\
\text {---------Rp--------- }\end{array}$ & $\begin{array}{c}\text { Persentase } \\
-----\%----\end{array}$ \\
\hline & Ragi & $3.285,18$ & 2,97 \\
\hline & Kayu & $49.882,35$ & 45,13 \\
\hline
\end{tabular}




\begin{tabular}{|c|c|c|c|}
\hline 3. & Plastik & $49.558,82$ & 44,84 \\
\hline 4. & Transportasi & $7.794,12$ & 7,05 \\
\hline & Total & $110.520,47$ & 100,00 \\
\hline & Sumbangan Input Lain/kg kedelai & $1.745,00$ & \\
\hline
\end{tabular}

Sumber: Data primer penelitian yang diolah, 2019.

Rata-rata biaya sumbangan input lain pada usaha tempe sebesar Rp 1.745 per $1 \mathrm{~kg}$ kedelai. Sumber biaya paling besar yang digunakan untuk memproduksi tempe per proses produksi adalah biaya penggunaan kayu yaitu rata-rata $\mathrm{Rp}$ 49.882,35 (45,13\%). Biaya sumbangan input lain yang paling rendah terletak pada biaya penggunaan ragi yaitu rata-rata $\mathrm{Rp} 3.285,18$ (2,97\%), kemudian penggunaan biaya transportasi yaitu rata-rata sebesar Rp 7.794,12 (7,05\%), dan diikuti oleh penggunaan biaya plastik yaitu rata-rata sebesar Rp 49.558,82 (44,84\%). Biaya penggunaan ragi paling sedikit dikarenakan harga ragi yang murah dan takaran penggunaannya juga sedikit sesuai dengan cuaca yang terjadi selama proses pembuatan tempe.

3. Tenaga Kerja

Biaya tenaga kerja dinilai berdasarkan hari orang kerja (HOK). Rata-rata biaya tenaga kerja pada usaha tempe di Desa Angkatan Lor terdapat pada Tabel 4.

Tabel 4. Rata-Rata Biaya Tenaga Kerja Usaha Tempe per Produksi Tahun 2019

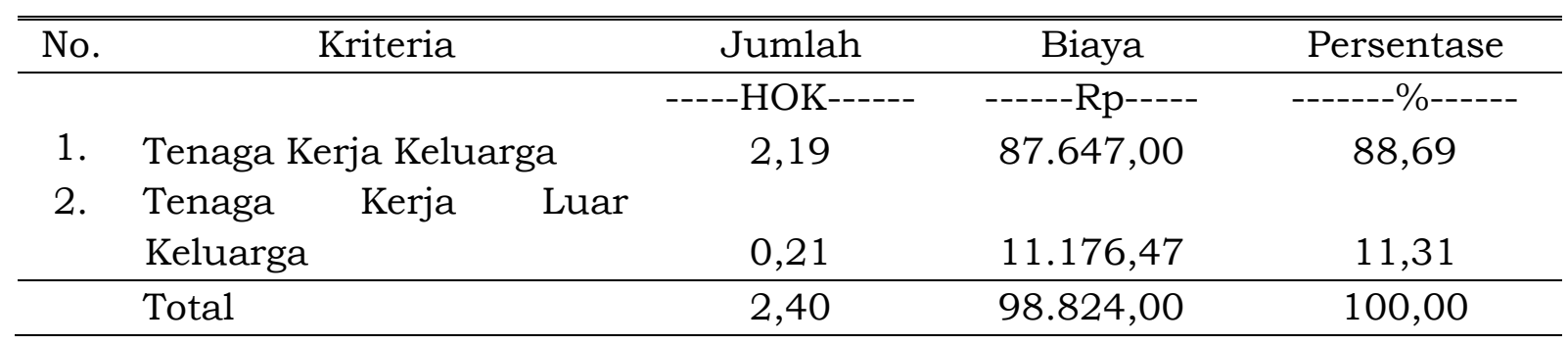

Sumber: Data primer penelitian yang diolah, 2019.

Tenaga kerja dalam yang digunakan untuk memproduksi tempe rata-rata yaitu 2,19 HOK dengan biaya sebesar Rp 87.647 untuk sekali produksi atau 88,69\%. Rata-rata tenaga kerja luar hanya 0,21 HOK dengan biaya sebesar Rp 11.176,47 atau $11,31 \%$. Rata-rata total tenaga kerja untuk membuat tempe yaitu 2,40 HOK dengan biaya sebesar Rp 98.824. Biaya tenaga kerja dalam lebih besar dari pada biaya tenaga kerja luar dikarenakan mayoritas usaha pembuatan tempe yang dijalankan oleh para pengrajin tempe masih berskala kecil sehingga tidak membutuhkan banyak tenaga kerja luar.

a. Biaya Total

Biaya total adalah jumlah biaya tetap dan biaya variabel yang dikeluarkan untuk membuat tempe. Rata-rata biaya total pembuatan tempe dalam sekali produksi yaitu sebesar Rp 576.737,06.

\section{Analisis Nilai Tambah}

Nilai tambah merupakan besarnya nilai yang diperoleh dari pengolahan kedelai menjadi tempe. Hasil analisis nilai tambah kedelai sebagai bahan baku tempe di Desa Angkatan Lor dapat dilihat pada Tabel 5. 
Tabel 5. Rata-Rata Nilai Tambah Tempe di Desa Angkatan Lor per Produksi 2019

\begin{tabular}{clc}
\hline No. & \multicolumn{1}{c}{ Variabel } & Nilai \\
\hline \multicolumn{1}{c}{ Tempe, Kedelai dan Harga } \\
\hline 1. & Tempe (kg) & 111,25 \\
2. & Kedelai (kg) & 65,44 \\
3. & Tenaga Kerja (HOK) & 2,40 \\
4. & Faktor Konversi (kg) & 1,70 \\
5. & Koefisien Tenaga Kerja (HOK/kg) & 0,05 \\
6. & Harga Tempe (Rp/kg) & $8.591,24$ \\
7. & Upah Tenaga Kerja (Rp/produksi) & $40.613,00$ \\
\hline & Penerimaan dan Keuntungan & $7.723,53$ \\
\hline 8. & Harga Kedelai (Rp/kg) & $1.745,44$ \\
9. & Sumbangan Input Lain (Rp/kg) & $14.605,11$ \\
10. & Nilai Tempe (Rp/kg) & $5.136,14$ \\
11. & a. Nilai Tambah (Rp/kg) & 34,65 \\
& b. Rasio Nilai Tambah (\%)
\end{tabular}

Sumber: Data primer penelitian yang diolah, 2019.

Berdasarkan Tabel 5. menunjukkan jumlah tempe yang dihasilkan per proses produksi oleh pengrajin tempe di Desa Angkatan Lor rata-rata yaitu $111,25 \mathrm{~kg}$ tempe. Tempe dijual dengan harga rata-rata Rp 8.591,24 per kg. Rata-rata pemakaian bahan baku yaitu kedelai sebesar 65,44 kg dengan harga kedelai $\mathrm{Rp}$ $7.723,53$ per kg. Perbandingan jumlah output dan input akan dihasilkan nilai faktor konversi sebesar 1,70 yang artinya pengolahan satu kg kedelai akan dihasilkan 1,70 kg tempe.

Pembuatan tempe menggunakan tenaga kerja keluarga dan tenaga kerja luar keluarga. Jumlah tenaga kerja yang dibutuhkan untuk mengolah tempe rata-rata sebesar 2,4 HOK per produksi. Perbandingan total tenaga kerja dengan kedelai yang digunakan menghasilkan keofisien sebesar 0,05 yang artinya untuk mengolah satu kg kedelai membutuhkan 0,05 HOK. Penggunaan tenaga kerja dibedakan menjadi tenaga kerja produksi (tahap perendaman sampai peragian) dan tahap pengemasan.

Biaya rata-rata tenaga kerja dihitung dari perbandingan antara biaya jumlah tenaga kerja dengan jumlah hari orang kerja dalam sekali proses produksi tempe. Besarnya upah rata-rata yang diterima pengrajin tempe sebesar Rp 40.613/HOK. Upah yang diterima merupakan balas jasa dari pengolahan tempe.

Biaya sumbangan input lain per kilogram kedelai yaitu sebesar Rp 1.745,44. Nilai tambah yang dihasilkan sebesar Rp 5.136,14 per kg kedelai dengan rasio sebesar $34,65 \%$. Nilai rasio tersebut menunjukkan bahwa nilai output sebesar Rp100,00 menunjukkan nilai tambah sebesar sebesar Rp 34,65.

Industri tempe di Desa Angkatan Lor mampu menghasilkan nilai tambah yang tegrolong sedang karena lebih dari 15\%. Hal ini sesuai dengan pendapat Maulidah dan Kusumawardani (2011) yang menyatakan bahwa rasio nilai tambah digolongkan menjadi 3 yaitu rasio nilai tambah rendah jika persentasenya $<15 \%$, rasio nilai tambah sedang jika persentasenya antara $15 \%-40 \%$ dan rasio nilai tambah tinggi jika persentasenya $>40 \%$. 


\section{Hasil Uji One Sample T Test}

Hasil uji one sample $t$ test menunjukan bahwa nilai signifikansi sebesar 0,00 $\leq$ 0,05 maka HO ditolak dan Ha diterima sehingga rasio nilai tambah yang dihasilkan dari usaha tempe berbeda sangat nyata dengan standar rasio nilai tambah yang telah ditetapkan. Kesimpulan dari uji statistik menunjukkan bahwa rasio nilai tambah tergolong sedang karena lebih dari 15\%. Menurut Maulidah dan Kusumawardani (2011), rasio nilai tambah tergolong sedang jika persentasenya antara $15-40 \%$.

Tabel 6. Hasil Uji Regresi Linear Berganda

\begin{tabular}{llllll}
\hline No. & Variabel Bebas & Koefisien Regresi & $\mathrm{t}$ & Sig & Ket \\
\hline 1. & Jumlah Kedelai (X1) & $-0,819$ & $-0,598$ & 0,554 & \\
2. & Harga Tempe (X2) & 1,763 & 21,210 & 0,00 & \\
\hline 3. & Sumbangan Input Lain (X3) & $-0,969$ & $-3,413$ & 0,002 & \\
\hline & Variabel terikat & \multicolumn{2}{c}{$:$ Nilai Tambah } & \\
& Konstanta & & $:-8.267,566$ & \\
& R square $\left(\mathrm{R}^{2}\right)$ & $: 0,944$ & & \\
& F hitung & $: 170,001$ & & \\
& Sig. & $: 0,00$ & & \\
\hline
\end{tabular}

Sumber: Data primer penelitian yang diolah, 2019.

\section{Analisis Regresi Linear Berganda}

Berdasarkan Tabel 6. dapat diketahui persamaan regresi linear berganda sebagai berikut:

$$
Y=-8.267,566-0,819 X_{1}+1,763 X_{2}-0,969 X_{3}
$$

Nilai konstanta sebesar $-8.267,566$. Nilai tersebut menunjukkan apabila jumlah kedelai, harga tempe dan sumbangan input lain nilainya 0 , maka nilai tambah nilainya negatif $8.267,566$. Koefisien regresi jumlah kedelai sebesar $-0,819$ menunjukkan apabila jumlah kedelai naik sebesar satu nilai maka nilai tambah akan turun sebesar 0,819 dengan asumsi variabel yang lain bernilai tetap. Hal ini dikarenakan kenaikan jumlah kedelai tidak sebanding dengan jumlah tempe yang dihasilkan. Apabila jumlah tempe yang dihasilkan sedikit maka faktor konversi akan rendah sehingga akan menurunkan nilai output tempe yang berasal dari perkalian antara harga tempe dan faktor konversi.

Koefisien regresi harga tempe sebesar 1,763 menunjukkan jika harga tempe sebesar satu nilai maka nilai tambah akan naik sebesar 1,763 dengan syarat variabel yang lain bernilai tetap. Semakin mahal harga tempe maka akan menaikkan nilai output sehingga nilai tambah juga akan naik.

Koefisien regresi sumbangan input lain sebesar -0,969 menunjukkan jika sumbangan input lain naik sebesar satu nilai maka nilai tambah akan turun sebesar 0,969 dengan syarat variabel yang lain bernilai tetap. Semakin besar sumbangan input lain namun nilai output tetap maka nilai tambah akan semakin rendah karena nilai tambah dihitung dari nilai output dikurangi sumbangan input dan harga kedelai. 
Berdasarkan Tabel 6. dapat diketahui bahwa $\mathrm{R}^{2}$ sebesar 0,944 atau 94,4\% yang berarti $94,4 \%$ nilai tambah dipengaruhi oleh jumlah kedelai, harga tempe dan sumbangan input, sedangkan variabel lain berpengaruh sebanyak 5,6\%. dipengaruhi oleh variabel lain. Nilai $\mathrm{F}$ hitung 170,001 > F tabel 3,30 dan nilai signifikansi F 0,00 kurang dari 0,05 yang artinya jumlah kedelai, harga tempe dan sumbangan input lain secara bersama-sama berpengaruh terhadap nilai tambah tempe.

Hasil uji t menunjukkan bahwa jumlah kedelai memiliki nilai signifikansi 0,554 > 0,05 sehingga nilai tambah tidak dipengaruhi secara nyata oleh jumlah kedelai. Harga tempe memiliki nilai signifikansi $0,00<0,05$ yang artinya harga tempe berpengaruh secara nyata terhadap nilai tambah. Nilai signifikansi sumbangan input lain sebesar 0,002 < 0,05 sehingga berpengaruh nyata terhadap nilai tambah. Jumlah kedelai memilki $t_{\text {hitung }}(0,598)<t_{\text {tabel }}(1,693)$, menunjukkan bahwa tidak ada pengaruh jumlah kedelai terhadap nilai tambah tempe. Harga tempe memiliki $t_{\text {hitung }}(21,210)>t_{\text {tabel }}(1,693)$, menunjukkan bahwa harga tempe berpengaruh nyata terhadap nilai tambah tempe. Sumbangan input lain memiliki $t_{\text {hitung }}(3,413)>t_{\text {tabel }}(1,693)$, menunjukkan bahwa sumbangan input lain berpengaruh nyata terhadap nilai tambah tempe.

\section{KESIMPULAN DAN SARAN}

\section{Kesimpulan}

Usaha tempe di Desa Angkatan Lor layak untuk dikembangkan karena menghasilkan nilai tambah walaupun tergolong sedang. Jumlah kedelai tidak berpengaruh secara nyata terhadap besarnya nilai tambah, sedangakan sumbangan input lain dan harga tempe berpangaruh secara nyata terhadap besarnya nilai tambah.

\section{Saran}

Sebaiknya pengrajin tempe menurunkan biaya sumbangan input lain terutama pada biaya bahan bakar untuk meningkatkan nilai tambah tempe. Nilai tambah tempe juga dapat ditingkatkan dengan cara menaikkan harga jual tempe.

\section{DAFTAR PUSTAKA}

Agustina, D.R, R.H. Ismono, dan A. Nugraha. 2015. Harga pokok produksi, nilai tambah, dan prospek pengembangan agroindustri marning di Kecamatan Gedong Tataan Kabupaten Pesawaran. JIIA. 3(2): 157-164. http://jurnal.fp.unila.ac.id/index.php/JIA/article/view/1034/939. September 2016].

Arum, W.P., S. Widjaya, dan L. Marlina. 2017. Kelayakan usaha dan nilai tambah agroindustri tempe. J. Ilmu-Ilmu Agribisnis. 5 (2): 124-133.

Badan Pusat Statistik. 2016. Susenas: Rata-Rata Konsumsi Per Kapita Seminggu Menurut Komoditi Makanan dan Golongan Pengeluaran. Badan Pusat Statitsik Jakarta. Tidak Dipublikasikan. 
Engko, C. 2008. Pengaruh kepuasan kerja terhadap kinerja individual dengan self esteem dan self efficacy sebagai variabel intervening. J. Bisnis dan Akuntansi. 10(1): 1-12.

Hayami, Y., K. Thosinori, M. dan M. Siregar. 1987. Agricultural Marketing and Processing in Upland Java: A prospectif from a Sunda Village, Bogor.

Januardie, M. R. 2012. Analisis Nilai Tambah Agroindustri Tempe di Kelurahan Medokan Ayu Kota Surabaya.Fakultas Pertanian Universitas Pembangunan Nasional "Veteran", Jawa Timur. (Skripsi)

Krisdiana, R. 2014. Penyebaran varietas unggul kedelai dan ekonomi perdesaan. J. Penelitian Pertanian Tanaman Pangan. 33 (1): 61-69.

Maulidah, S. dan F. Kusumawardani. 2011. Nilai tambah agroindustri belimbing manis dan optimasi output sebagai upaya peningkatan pendapatan. Agrise 9(1): 1412-1425.

Purnamasari, D.A. 2017. Analisis Nilai Tambah Industri Rumah Tangga Tempe di Desa Pliken Kecamatan Kembaran Kabupaten Banyumas. Fakultas Pertanian Universitas Gajah Mada, Yogyakarta. (Skripsi).

Putri, A.D. dan N.D. Setiawina. 2013. Pengaruh umur, pendidikan, pekerjaan terhadap pendapatan rumah tangga miskin di Desa Bebandem. J. Ekonomi Pembangunan Fakultas Ekonomi Universitas Udayana. 2(4): 173-180.

Rayandi, D. S. 2008. Panduan Wirausaha Tempe. Buku Kita, Jakarta.

Riduwan. 2010. Dasar-Dasar Statistika. Alfabeta, Bandung.

Salim, E. 2012. Kiat Cerdas Wirausaha Aneka Olahan Kedelai. Penerbit Andi, Yogyakarta.

Soehyono, F., D. Rochdiani, M.N. Yusuf. 2014. Analisis Usaha dan Nilai Tambah Agroindustri Tempe (Suatu Kasus di Kelurahan Banjar Kecamatan Banjar Kota Banjar). J. Ilmiah Mahasiswa Agroinfo Galuh. 1(1): 43-50.

Suprapti, M. L. 2007. Pembuatan Tempe. Cetakan Ke-5. Penerbit Kanisius, Yogyakarta.

Syaifuddin, A. 2013. Strategi Pengembangan Sektor Pertanian Sub Sektor Tanaman Pangan dalam Upaya Peningkatan PBRB Kabupaten Pati. J. Ekonomi Pembangunan. 2 (1): 1-6.

Tambunan, V. dan N. Woyanti. 2012. Analisis pengaruh pendidikan, upah, insentif, jaminan social dan pengalaman kerja terhadap produktivitas tenaga kerja di Kota Semarang (studi kasus Kecamatan Banyumanik dan Kecamatan Gunung Pati). Diponegoro Journal of Economics. 1 (1): 1-11. 